\title{
Low expression of bcl-2 in Brca1-associated breast cancers
}

\author{
P Freneaux'1, D Stoppa-Lyonnet ${ }^{2}$, E Mouret ${ }^{3}$, M Kambouchner', A Nicolas', B Zafrani', A Vincent-Salomon', \\ A Fourquet $^{4}$, H Magdelenat ${ }^{5}$ and X Sastre-Garau ${ }^{1}$ \\ ${ }^{1}$ Departments of Pathology; ${ }^{2}$ Genetics; ${ }^{3}$ Biostatistics; ${ }^{4}$ Radiotherapy; and ${ }^{5}$ Physiopathology, Institut Curie, 26 Rue d'Ulm, 75248, Paris cedex 05, France
}

\begin{abstract}
Summary Little data are available concerning the molecular mechanisms of action of Brca1 and Brca2 in breast oncogenesis. Recent experimental results suggest that Brca1 plays a role in the regulation of apoptosis. In order to determine whether the analysis of human tumours would provide data supporting this hypothesis, we have assessed the expression of the antiapoptotic bcl-2 and of the proapoptotic p53 genes in Brca1- and Brca2-associated breast carcinomas. The levels of expression of these genes were compared to those observed in controls and to the mitotic and the apoptotic indexes. Our series were composed of 16 cases of breast carcinoma in women with a germline Brca1 gene mutation, and of four cases with Brca2 mutation. A group of 39 patients aged under 36 years and for whom the search for Brca1 gene mutations was negative, and a group of 36 cases of sporadic cancers without data on their Brca status were used as controls. Immunohistochemistry was used to detect p53 and bcl-2 gene products. Mitotic and apoptotic indexes were higher in Brca1-associated tumours than in controls. No significant difference in p53 immunostaining was observed between the four groups of patients. In contrast, the rate of $b c /$-2-positive tumours was lower $(31 \%)$ in Brca1-carcinomas than in carcinomas without Brca1 mutation $(90 \%)\left(P<10^{-3}\right)$. A strong $\mathrm{Bcl}-2$ expression was found in the four cases of Brca2-associated carcinomas. No significant correlation was observed between p53 and Bcl2 immunostainings, either in cases or in controls. The association between Brca1 status and Bcl-2 expression remained significant after adjustment for the oestrogen receptor status. Our study shows that a low expression of $b c l-2$ characterises most Brca1-associated breast carcinomas, a biological trait which seems not to be shared by Brca2-associated tumours nor to be related to oestrogen receptor and/or p53 status. bcl-2 might thus be one of the target genes involved in the oncogenesis related to Brca1 and its down-regulation may account for the increased apoptosis and the high proliferative rate observed in Brca1-associated carcinomas. @ 2000 Cancer Research Campaign
\end{abstract}

Keywords: Brca1; Brca2; bcl-2; proliferation; apoptosis; breast cancer

Brcal and Brca2 germline mutations are frequently observed in women presenting breast carcinoma as part of an hereditary cancer susceptibility syndrome (Ford et al, 1998). The histological phenotype of $\mathrm{BrCa}$-associated breast tumours differs from that of sporadic cases: Brcal-associated tumours generally present as poorly differentiated and highly mitotic carcinomas (Jacquemier et al, 1995; Lakhani et al, 1998) whereas Brca2 tumours were reported to present a high (Agnarsson et al, 1998) or a low (Lakhani et al, 1998) mitotic index. However, no characteristic immunophenotype of these lesions has been reported so far (Robson et al, 1998), and little data are available regarding the biological mechanisms involved in the development of tumours associated with Brcal or 2 gene mutations. Using animal models, it was recently reported that the disruption of the Brcal alleles specifically in mouse mammary epithelium leads to increased apoptosis and to tumour formation (Xu et al, 1999). These findings prompted us to analyse the expression of the antiapoptotic $b c l-2$ and of the proapoptotic $p 53$ genes in a series of Brcal- and Brca2-associated breast carcinomas, together with mitotic and apoptotic indexes, and to compare these values to those obtained in sporadic cancers.

Received 16 November 1999

Revised 26 June 2000

Accepted 29 June 2000

Correspondence to: $\mathrm{X}$ Sastre-Garau
This analysis showed that, whereas no difference in $p 53$ expression was observed between the different groups, Brcal-associated tumours dysplayed a low rate of $b c l-2$ expression and high mitotic and apoptotic indexes. The decrease in $b c l-2$ expression was found to be independent from hormone receptor status and may account for the high apoptotic and proliferative rates observed in Brcalassociated tumours.

\section{MATERIAL AND METHODS}

Sixteen women affected with a breast carcinoma before the age of 36 were detected to be carriers of a germline Brcal mutation through the Brcal analysis of a series of 123 early-onset consecutive cases as reported in a previous study (Ansquer et al, 1998). The corresponding 16 tumours were analysed and correspond to the group of cases. A first control group was constituted by a series of 39 women from the early-onset series identified as non-Brcal carriers. Tumours of 36 sporadic cases, untested for Brcal and Brca 2 mutation, constituted a second control group. The former group has been chosen to avoid a possible bias related to the fact that tumours occurring in young women might present a characteristic immunophenotype independently from their Brca status. In addition, the tumours of four women belonging to the early-onset breast carcinomas series and identified as carrier of a germline Brca 2 mutation were also studied. $p 53$ and $b c l-2$ gene expression was assessed by immunohistochemistry using anti-p53 (D0-7) and 
Table 1 Clinicopathological characteristics of patients and tumours according to the Brca status

\begin{tabular}{|c|c|c|c|c|c|}
\hline \multirow[t]{2}{*}{ Parameters } & \multicolumn{2}{|c|}{ Cases } & \multicolumn{2}{|c|}{ Controls } & \multirow[t]{2}{*}{$P^{a}$} \\
\hline & $\begin{array}{c}\text { Brca1 } \\
\text { mutation }\end{array}$ & $\begin{array}{c}\text { Brca2 } \\
\text { mutation }\end{array}$ & $\begin{array}{l}\text { No Brca1 } \\
\text { mutation }\end{array}$ & $\begin{array}{l}\text { Sporadic } \\
\text { tumours }\end{array}$ & \\
\hline Number of cases & 16 & 4 & 39 & 36 & - \\
\hline \multicolumn{6}{|l|}{ Patient's age } \\
\hline median & 34 & 50.5 & 33 & 62.5 & - \\
\hline $\operatorname{mini}-\operatorname{maxi}$ & $25-47$ & $49-52$ & $21-36$ & $31-80$ & \\
\hline \multicolumn{6}{|l|}{ Tumour size } \\
\hline$\leq 20 \mathrm{~mm}$ & $5(31.2 \%)$ & $2(50 \%)$ & $17(43.6 \%)$ & $9(25 \%)$ & \\
\hline$>20$ mm & $11(68.8 \%)$ & $2(50 \%)$ & 22 (56.4\%) & 27 (75\%) & $\mathrm{ns}$ \\
\hline \multicolumn{6}{|l|}{ Node status } \\
\hline No & $6(37.5 \%)$ & $3(75 \%)$ & 26 (66.7\%) & 26 (72.2\%) & \\
\hline $\mathrm{N} 1$ & $10(62.5 \%)$ & 0 & $13(33.3 \%)$ & $9(25 \%)$ & $4.6 \times 10^{-2}$ \\
\hline N2 & 0 & $1(25 \%)$ & 0 & $1(2.8 \%)$ & \\
\hline \multicolumn{6}{|l|}{ Histological grade } \\
\hline I & 0 & 0 & $3(7.7 \%)$ & 7 (19.4\%) & \\
\hline II & $4(25 \%)$ & $1(25 \%)$ & $27(69.2 \%)$ & $16(44.4 \%)$ & $3.10^{-4}$ \\
\hline III & $12(75 \%)$ & $3(75 \%)$ & $9(23.1 \%)$ & $13(36.2 \%)$ & \\
\hline Mitotic index & 14.5 & 5.5 & 4 & 8 & $9.10^{-3}$ \\
\hline Apoptotic index & 10 & 9 & 7 & nd & $2.10^{-2}$ \\
\hline \multicolumn{6}{|l|}{ Hormonal status } \\
\hline ER-positive & $3(21.4 \%)$ & $4(100 \%)$ & $27(71.1 \%)$ & 26 (74.3\%) & $10^{-3}$ \\
\hline PR-positive & $7(46.7 \%)$ & $3(75 \%)$ & $28(73.7 \%)$ & $23(65.7 \%)$ & ns \\
\hline nd & 3 & & 1 & 1 & \\
\hline \multicolumn{6}{|l|}{$\mathrm{Bcl}-2$ status } \\
\hline positive cases & $5(31 \%)$ & $4(100 \%)$ & $35(90 \%)$ & 27 (77\%) & $<10^{-3 c}$ \\
\hline \multicolumn{6}{|l|}{ P53 status } \\
\hline positive cases & 9 (56.2\%) & 0 & 24 (61.5\%) & $13(38.2 \%)$ & ns \\
\hline
\end{tabular}

${ }^{a}$ Brca1 cases vs no Brca1 mutation; ${ }^{b}$ median of indexes; ${ }^{\circ}$ Chi-squared test with Yate's correction; $n d=$ not determined; $n s=$ not significant

anti-Bcl-2 (124) monoclonal antibodies (Dako A/S, Glostrup, Denmark). The threshold of positivity was $5 \%$ of malignant stained cells for $\mathrm{p} 53$ and $1 \%$ for Bcl-2. Proliferation rate was determined by counting the number of mitotic features in ten successive microscopic fields at $\mathrm{G} \times 400$, as recommended for the evaluation of the Nottingham histological grade (Elston and Ellis, 1991; Genestie et al, 1998). Apoptotic index was assessed on haematoxylin-eosin-coloured histological sections by counting nuclear and/or cytoplasmic features characterising the apoptotic process (Bessis, 1964; Cummings et al, 1997). In every case, a tumour area presenting the highest number of apoptotic features was determined at low magnification, then analysed at high power field $(G \times$ 400). After image capture, apoptotic features were pointed on the screen and scored using an image analysis system (Perfect Image; Clara Vision, Orsay, France). The apoptotic index was defined as the ratio between this count and the total number of invasive malignant cells. The counting was performed on successive fields when less than 100 invasive malignant cells were present on a single field.

The association between Brcal gene mutation and tumour characteristics was evaluated using the Chi-squared test with Yate's correction when necessary for discrete variables (tumour size, nodal status, histological grade, hormonal status, $b c l-2$ status, $p 53$ status) and the Mann-Whitney test for continuous variables (age, mitotic index, apoptotic index). Logistic regression was used to assess the independent association of factors for Brcal gene mutation identified in univariate analysis, in a group of tumours for which all clinical and pathological data were available (52 tumours), i.e. 13 cases with Brcal mutation and the 39 controls with no Brcal mutation. All variables with $P$ value $<0.05$ were introduced in the initial multivariate model (excepted mitotic and apoptotic indexes) and deleted through a backward procedure. Variables with a significance level of 0.05 were kept in the final model.

\section{RESULTS}

Our analysis showed that a higher histological grade $\left(P=3 \cdot 10^{-4}\right)$, a higher mitotic index $\left(P=9.10^{-3}\right)$, a higher apoptotic index $(P=$ $\left.2.10^{-2}\right)$ and a lower rate of oestrogen receptor positivity $\left(P=10^{-3}\right)$ were observed in Brcal-associated breast cancers than in controls (Table 1). A slight positive correlation was found between mitotic and apoptotic indexes $(r=0.28, P=0.045)$.

The immunohistochemical analysis found no significant difference in p53 immunostaining between the four groups of tumours. In contrast, a significant difference in $b c l-2$ expression was found between cases and either control groups (Figure 1). The rate of $b c l$ 2-positive tumours was lower (31\%) in Brcal-associated carcinomas than in sporadic tumours $(77 \%)\left(P=2 \cdot 10^{-3}\right)$. This difference was even more striking in comparison with the rate of $b c l$-2-positive tumours observed in young women without Brcal mutation $(90 \%)\left(P<10^{-3}\right)$. The four cases of Brca2-associated carcinoma were found to be positive. The mean number of labelled cells was $56 \%$ in the group of sporadic tumours and $45 \%$ in tumours with no Brcal mutation. In contrast, a complete absence of labeling was observed in 11 of the 16 cases of Brcal-associated carcinomas. A weak staining of $5 \%$ of the tumour cells was observed in one case whereas the remaining four cases exhibited $40-80 \%$ of labelled cells. The negative association of $b c l-2$ expression and Brcal-mutation remained significant after 

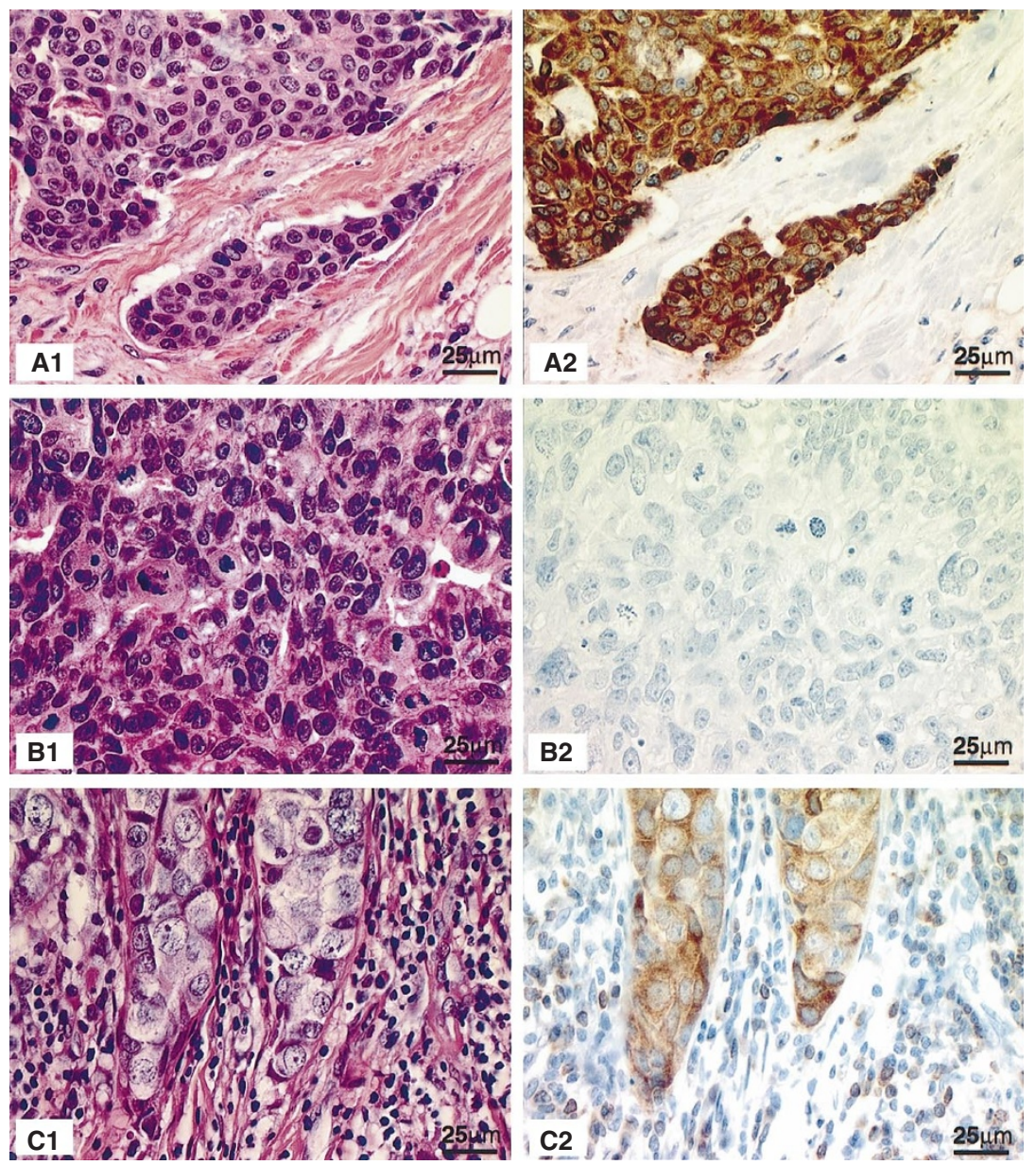

Figure 1 Histological aspects of sporadic invasive ductal carcinoma (A1), Brca1-associated (B1) and Brca2-associated (C1) carcinomas. Immunostainings of bcl-2 in these cases. High level of bcl-2 expression in sporadic cancer (A2) and in Brca2-associated carcinoma (C2). No expression detected in Brca1-associated carcinoma (B2)

adjustment on oestrogen receptor status. In multivariate logistic regression analysis, low expression of $b c l-2$ (odds ratio (OR) 13.9; 95\% CI 2.6-76.9) and high histological grade (OR 7.1; 95\% CI 1.3-38.8) were significant predictive variables associated with the presence of Brcal gene mutation (Table 2). No significant correlation was observed between p53 and Bcl-2 immunostaining, either in cases or in controls.

\section{DISCUSSION}

Our study shows that most Brcal-associated breast carcinomas are characterized by high mitotic and apoptotic rates, and by a decrease of $b c l-2$ expression. These biological traits seem not to be shared by Brca2-associated tumours and not related to oestrogen receptor and/or to p53 status. In an analysis of the immunophenotype of Brcaassociated tumours, only a slight decrease of $b c l-2$ expression was found in familial cancers in comparison with the level observed in controls (Robson et al, 1998). However, in this work, Brcal- and Brca2-tumours were included in the same group, and this could account for the negativity of the result. Recent data emphasize that different molecular pathogenetic processes characterize Brcal- and Brca2-associated tumours (Armes et al, 1999), and this is in agreement with our data on distinctive $b c l$-2-expression in these two tumour types.
High levels of $b c l-2$ expression have been observed in 75-80\% of cases of sporadic breast cancers (Leek et al, 1994; Silvestrini et al, 1994; Hellemans et al, 1995). This expression was found to be associated with the presence of favourable prognostic features (Joensuu et al, 1994) and with the expression of oestrogen and progesterone receptors (Barghava et al, 1994; Gee et al, 1994; Leek et al, 1994; Silvestrini et al, 1994; Hellemans et al, 1995; Charpin et al, 1997).

Since Brcal-associated breast carcinomas are frequently oestrogen receptor negative, poorly differentiated tumours, and since a positive association exists between the respective expression of oestrogen receptor (ER) and $b c l-2$, the down-regulation of $b c l-2$ in Brcal-associated carcinomas might merely reflect the down regulation of ER in this type of tumour. In our study, the loss of $b c l-2$ expression characterizing Brcal-associated carcinomas behaved as a biological trait independent from the ER status of the tumours. Definitive conclusions cannot be drawn from this multivariate analysis considering the limited number of cases included in this series. However, it is worth mentioning that in multivariate analyses of prognostic factors characterizing large series of axillary node-positive breast tumours, the lack of $b c l-2$ expression was found associated with a poor outcome of the disease, independently from the ER status (Hellemans et al, 1995; Berardo et al, 1998). 
Table 2 Association of biological parameters with Brca1 gene mutation in logistic regression model ${ }^{\mathrm{a}}$

\begin{tabular}{|c|c|c|c|}
\hline $\begin{array}{l}\text { Biological } \\
\text { parameters }\end{array}$ & OR & $95 \% \mathrm{Cl}$ & $P$ value \\
\hline \multicolumn{4}{|c|}{$B c l-2$ expression } \\
\hline high & 1 & & \\
\hline low & 13.9 & $2.6-76.9$ & 0.002 \\
\hline \multicolumn{4}{|c|}{ histological grade } \\
\hline $\mathrm{I} / \mathrm{II}$ & 1 & & \\
\hline III & 7.1 & $1.3-38.8$ & 0.02 \\
\hline
\end{tabular}

The molecular mechanisms of action of Brcal in the tumour process are poorly understood. The observation of increased apoptosis in mouse mammary tissue triggered by the inactivation of the two copies of the Brcal gene (Xu et al, 1999) suggest that the Brcal gene products could function as transcriptional regulators of (Yang and Lippman, 1999). The anti-apoptotic bcl-2 might be one of the target genes for Brcal in such mechanisms. Our present data reporting a down-regulation of $b c l-2$ and a high apoptotic index of Brcal-associated carcinomas support this hypothesis. Another line of evidence indicates that Brcal plays a positive role in the control of cell growth (Gudas et al, 1996). bcl2 gene product could also act as a second messenger in this control: an inhibitory effect of entry into the cell cycle has been reported for $b c l-2$ (O'Reilly et al, 1996). and this effect was found genetically separable from the functions of the protein in cell survival (Huang et al, 1997). The high proliferative rate observed in Brcal-, but not in Brca2-associated tumours (Armes et al, 1999), might thus be related to the respective levels of $b c l-2$ expression in these tumours. It is worth mentioning that a positive link between proliferation and apoptosis has already been observed in carcinomas of the breast (Dowsett et al, 1999), and that the loss of $b c l-2$ has been found to be associated with both increased apoptosis and increased proliferative rates in sporadic breast cancers (van Slooten et al, 1998). In such cases, it would be of interest to determine whether this loss was associated with a down-regulation of Brcal, the implication of which in the progression of sporadic breast carcinomas is also a matter of speculation (Yang and Lippman, 1999).

The similarity in p53 immunostaining between Brcal-and non Brcal-associated tumours is in agreement with our previous results reporting a similar pattern in p53 mutations in these two groups of tumours (Schlichtholz et al, 1998). These results are at discrepancy with data reporting a high rate of p53 mutation in a small group of Brcal-associated carcinomas (Crook et al, 1997). It is worth mentioning that a very large diversity of p53 mutational patterns is observed among cohorts of sporadic breast cancers (Hartmann et al, 1997). These variations may also concern familial tumours and thus account, at least in part, for the discrepancies observed between the rates of p53 alterations in these tumours. Furthermore, the biological consequence of p53 cell accumulation, as determined by immunohistochemistry, is unclear and the link between p53-positive immunostaining and gene mutation is inconstant in breast cancers (Sjögren et al, 1996). No correlation was observed between $p 53$ and $b c l-2$ immunostaining in our study, a result already reported by others (Silvestrini et al, 1996).
In conclusion, a low $b c l-2$ expression and high proliferative and apoptotic rates characterize most Brcal-associated breast carcinomas. The analysis of a large series of cases including the assessment of the expression of $\mathrm{bcl}-2$, of Brcal and of biological parameters associated with cell death and proliferation, should help to determine whether alterations of the functions of Brcal gene product were responsible for the down-regulation of $b c l-2$, and thus for the high proliferative rate and increased apoptosis observed in Brcal-associated carcinomas.

\section{ACKNOWLEDGEMENTS}

We thank Dr Jérôme Couturier for helpful discussion. This work was supported in part by a grant from the Lion's Club (Moulins/s/Allier).

\section{REFERENCES}

Agnarsson B, Jonasson J, Bjornsdottir I, Barkardottir R, Egilsson V and Sigurdsson $\mathrm{H}$ (1998) Inherited BRCA2 mutation associated with high grade breast cancer. Breast Cancer Res Treat 47: 121-127

Ansquer Y, Gautier C, Fourquet A, Asselain B, Stoppa-Lyonnet D and the Institut Curie Breast Cancer Group (1998) Survival in early-onset BRCA1-cancer patients. Lancet 352: 541

Armes J, Trute L, White D, Southey C, Hammet F, Tesoriero A, Hutchins A, Dite G, McCredie M, Giles G, Hopper J and Venter D (1999) Distinct molecular pathogeneses of early-onset breast cancers in BRCA1 and BRCA2 mutation carriers: a population-based study. Cancer Res 59: 2011-2017

Barghava V, Kell D, van de Rijn M and Warnke R (1994) Bcl-2 immunoreactivity in breast carcinoma correlates with hormone receptor positivity. Am J Pathol 145: 535-540

Berardo M, Elledge R, de Moor C, Clark G, Osborne K and Allred C (1998) bcl-2 and apoptosis in lymph node positive breast carcinoma. Cancer 82: 1296-1302

Bessis M (1964) Studies on cell agony and death: an attempt at classification. In Ciba Foundation Symposium on Cellular Injury AVS de Reuck and J Knight (eds). J \& A Churchill Ltd: London

Charpin C, Garcia S, Bouvier C, Devictor B, Andrac L, Lavaut M.-N and Allasia C (1997) Automated and quantitative immunocytochemical assays of Bcl-2 protein in breast carcinomas. Br J Cancer 76: 340-346

Crook T, Crossland S, Crompton M, Osin P and Gusterson B (1997) p53 mutations in BRCA 1-associated familiar breast cancer. Lancet 350: 638-639

Cummings M, Winterford C and Walker N (1997) Apoptosis. Am J Surg Pathol 21: 88-101

Dowsett M, Smith I, Powles T, Salter J, Ellis P, Johnston S, Makris A, Mainwaring P, Gregory R, Archer C, Chang J and Assersohn L (1999) Biological studies in primary medical therapy of breast cancer: The Royal Marsden Hospital experience. In ESO Scientific Updates, Vol 4. Primary Medical Therapy for Breast Cancer: Clinical and Biological Aspects, A. Howell and M. Dowsett (eds) pp 113-125. Elsevier Science: London

Elston C and Ellis I (1991) Pathological prognostic factors in breast cancer. I. The value of histological grade in breast cancer: experience from a large study with long-term follow-up. Histopathol 19: 403-410

Ford D, Easton D, Stratton M, Narod S, Goldgar D, Devilee P, Bishop D, Weber B, Lenoir G, Chang-Claude J, Sobol H, Teare M, Struewing J, Arason A, Scherneck S, Peto J, Rebbeck T, Tonin P, Neuhausen S, Barkardottir R, Eyfjord J, Lynch H, Ponder B, Gayther S, Birch J, Lindblom A, StoppaLyonnet D, Bignon Y, Borg A, Hamann U, Haites N, Scott R, Maugard C, Vasen H, Seitz S, Cannon-Albright L, Schofield A, Zelada-Hedman M and Consortium BCL (1998) Genetic heterogeneity and penetrance analysis of the BRCA1 and BRCA2 genes in breast cancer families. Am J Hum Genet 62: 676-689

Gee J, Robertson J, Ellis I, Willsher P, McClelland R, Hoyle H, Kyme S, Finlay P, Blamey R and Nicholson R (1994) Immunocytochemical localization of BCL-2 protein in human breast cancers and its relationship to a series of prognostic markers and response to endocrine therapy. Intl J Cancer 59: 619-628

Genestie C, Zafrani B, Asselin B, Fourquet A, Rozan S, Validire P, Vincent-Salomon A and Sastre-Garau X (1998) Comparison of the respective prognostic values of Scarff-Bloom-Richardson and Nottingham histological grade in a series of 825 cases of breast cancer. Major importance of the mitotic count as a 
component of both grading systems. Anticancer Res 18: 571-576

Gudas J, Li T, Nguyen H, Jensen D, Rauscher F and Cowan K (1996) Cell cycle regulation of BRCAl messenger RNA in human breast epithelial cells. Cell Growth Differ 7: 717-723

Hartmann A, Blaszyk H, Kovach J and Sommer S (1997) The molecular epidemiology of P53 gene mutations in human breast cancer. Trends Genet 13: $27-33$

Hellemans P, van Dam P, Weyler J, van Oosterom A, Buytaert P and Van Marck E (1995) Prognostic value of $b c l-2$ expression in invasive breast cancer. $\mathrm{Br} J$ Cancer 72: 354-360

Huang D, O'Reilly L, Strasser A and Cory S (1997) The anti-apoptosis function of $\mathrm{Bcl}-2$ can be genetically separated from its inhibitory effect on cell cycle entry. EMBO J 16: 4628-4638

Jacquemier J, Eisinger F, Birnbaum D and Sobol H (1995) Histoprognostic grade in BRCA1-associated breast cancer. Lancet 345: 1503

Joensuu H, Pylkkänen L and Toikkanen S (1994) Bcl-2 protein expression and longterm survival in breast cancer. Am J Pathol 145: 1191-1198

Lakhani S, Jacquemier J, Sloane J, Gusterson B, Anderson T, van de Vijver M, Farid L, Venter D, Antoniou A, Storfer-Isser A, Smyth E, Steel M, Haites N, Scott R, Goldgar D, Neuhausen S, Daly P, Ormiston W, McManus R, Scherneck S, Ponder B, Ford D, Peto J, Stoppa-Lyonnet D, Bignon Y, Struewing J, Spurr N, Bishop D, Devilee P, Cornelisse C, Lasset C, Lenoir G, Bjork Barkardottir R, Egilsson V, Hamann U, Chang-Claude J, Sobol H, Weber B, Stratton M and Easton D (1998) Multifactorial analysis of differences between sporadic breast cancers and cancers involving BRCA1 and BRCA2 mutations. J Natl Cancer Inst 90: $1338-1345$

Leek R, Kaklamanis L, Pezzella F, Gatter K and Harris A (1994) bcl-2 in normal breast and carcinoma, association with oestrogen receptor-positive, epidermal growth factor receptor-negative tumours and in situ cancer. Br J Cancer 69: 135-139
O'Reilly L, Huang D and Strasser A (1996) The cell death inhibitor Bcl-2 and its homologues influence control of cell cycle entry. EMBO J 15: 6979-6990

Robson M, Rajan P, Rosen P, Gilewski T, Hirschaut Y, Pressman P, Haas B, Norton L and Offit K (1998) BRCA-associated breast cancer: absence of a characteristic immunophenotype. Cancer Res 58: 1389-1842

Schlichtholz B, Bouchind'homme B, Pages S, Martin E, Liva S, Magdelenat H, Sastre-Garau X, Stoppa-Lyonnet D and Soussi T (1998) p53 mutations in BRCA1-associated familial breast cancer. Lancet 352: 622

Silvestrini R, Benini E, Veneroni S, Daidone M, Tomasic G, Squicciarini P and Salvadori B (1996) p53 and bcl-2 expression correlates with clinical outcome in a series of node-positive breast cancer patients. J Clin Oncol 14: 1604-1610

Silvestrini R, Veneroni S, Daidone M, Benini E, Boracchi P, Mezzetti M, Di Fronzo G, Rilke F and Veronesi U (1994) The Bcl-2 protein: a prognostic indicator strongly related to 53 protein in lymph node-negative breast cancer patients. $J$ Natl Cancer Inst 86: 499-504

Sjögren S, Inganäs M, Norberg T, Lindgren A, Nordgren H, Holmberg L and Bergh J (1996) The p53 gene in breast cancer: prognostic value of complementary DNA sequencing versus immunohistochemistry. $J$ Natl Cancer Inst 88: 173-182

van Slooten H.-J, van de Vijver M, van de Velde C and van Dierendonck J (1998) Loss of Bcl-2 in invasive breast cancer is associated with high rates of cell death, by also with increased proliferative activity. Br J Cancer 77: 789-796

Xu X, Wagner K, Larson D, Weaver Z, Li C, Ried T, Hennighausen L, WynshawBoris A and Deng C (1999) Conditional mutation of Brcal in mammary epithelial cells results in blunted ductal morphogenesis and tumour formation. Nature Genet 22: 37-43

Yang X and Lippman M (1999) BRCA1 and BRCA2 in breast cancer. Breast Cancer Res Treat 54: 1-10 